\title{
Evaluation of road traffic noise pollution in Quetta (Pakistan)
}

\author{
H. U. khan*, Syed Imran Ali \\ Department of Physics, Balochistan University of Information Technology Engineering and Management Sciences, Quetta, Pakistan
}

Email address:

hamullah_khan@yahoo.com (H. U. khan)

To cite this article:

H. U. khan, Shoibullah Khan, Syed Imran Ali. Evaluation of Road Traffic Noise Pollution in Quetta (Pakistan). American Journal of Modern Physics. Vol. 3, No. 2, 2014, pp. 29-36. doi: 10.11648/j.ajmp.20140302.11

\begin{abstract}
Pakistan, like other developing countries, is facing the growing problem of traffic noise pollution of the modern world. It is a notable problem of urban areas of the country including Quetta city. The basic cause of this problem is the tremendous increase in traffic volume and lack of proper town planning. This study is the first proper attempt to evaluate the traffic noise level in Quetta city. To estimate the level of road traffic noise, the technique employed is a "regular grid over a map". This technique generated 60 observation locations across the city covering almost the whole city. The different zones are classified on the standards of US Department of Housing and Urban Development. The measuring points generated so have been divided into four categories depending upon the activities carried out in that region. It is observed that mixed area i.e. "commercial and residential" are at high risk, where the $\mathrm{L}_{\max }$ is $93.1 \mathrm{~dB}$ and the statistical analysis reveals the fact that the $77.1 \%$ of the locations in residential areas are higher than the standards set by the local authority. Noise map is also designed for future use and the better understanding of the traffic noise in Quetta city. It is observed that most of the population of the city is significantly exposed to the high noise level due to the unmitigated traffic noise.
\end{abstract}

Keywords: Noise, Expose, Residential, Traffics, Measurement

\section{Introduction}

Noise pollution is the consequence of urbanization and industrialization and is considered as major problem of urban areas. The most important factors raising noise pollution in urban areas include vehicular traffic, neighborhood electrical appliances, TV and music systems, public address systems, and railway and air traffic. Increase in noise level, across the world, has motivated the researchers of the world to this study the problem and its impact on the environment. Also, researchers have reported that the road traffic noise is the leading source of noise in urban areas [1]. Noise pollution is not only the growing problem of developing countries but also of the developed countries. According to researchers, over 130 million people in Europe suffer from exposure to noise levels above $65 \mathrm{~dB}(\mathrm{~A})[2]$.

The noise defined as a unwanted sound, either because of its effects on human or its effect on fatigue or malfunction of physical equipment, or its interference with the perception or detection of other sounds [3]. To comprehend the noise pollution in a better way we must understand the range of sound intensities for normal human. Human ear can detect the wide range of intensities, from threshold of hearing i.e. $1 \times 10^{-12} \mathrm{~W} / \mathrm{m}^{2}$ to the threshold of pan at 10 $\mathrm{W} / \mathrm{m}^{2}$, this range can express in terms of decibel by the following relation [4].

$$
\text { Intensity Level }=\beta=(10 \mathrm{~dB}) \log _{\mathrm{in}} \frac{I}{I_{0}}
$$

Where

$\beta=$ Is a constant defining intensity level.

$I_{o}=$ Reference sound intensity.

If $\beta$ becomes zero decibel ( $\mathrm{dB}$ ), no sound is heard by most people. Similarly, the sound intensity level at the threshold of pain is $130 \mathrm{~dB}$.

In many research conducted worldwide, especially in developed countries, road traffic noise is considered to be the worst environmental noise offender and a leading detriment to health and well-being in the community [5]. Noise can cause speech interfere, especially when the 
background noise level is $50 \mathrm{~dB}(\mathrm{~A})$, noise can also cause annoyance and can decrease work performance [6]. According to the World Health Organization, noise pollution is nowadays the third most hazardous environmental type of pollution, preceded only by air and water pollution [7]. Noise pollution has notable adverse impacts on the health of human beings. There is an increasing probability to heart disease among the peoples who are constantly living in the areas where the out door noise level is greater than 65-70 $\mathrm{dB}[8]$. Another survey reveals the fact that traffic noise is not only the main cause of headache, high BP, dizziness and fatigue at working place but is also badly interfering in daily life activities such as resting, reading, and communications [9]. A study among the workers exposed to road traffic noise disclosed a deep relationship between the exposure of traffic noise and the noise-induced hearing loss (NIHL)[10].

\section{Materials and Methods}

\subsection{Study Area}

Balochistan is the largest province by area, Pakistan and Quetta is the largest city and capital of Balochistan. Quetta is a beautiful valley, surrounded by mountains named: Chiltan, Takatoo,Murdar, and Zarghun. The city is an important gate way to Afghanistan and Central Asia. Quetta is known as the fruit garden of Pakistan.

British government had designed new Quetta city after earthquake of 1935 , only for 0.1 million people while now over two million populations is living in this city. With the increase in population, the number of vehicles has also been increased. The increase in the number of vehicles and lack of proper management has greatly increased the problem of noise pollution in Quetta city. No wonder, increase in population, lack of proper town planning and high traffic density has greatly increased traffic noise on all important roads of the city.

\subsection{Experimental Procedure}

Experimental procedure mainly includes method employed in taking readings from various roads of the city. Various methods are being used to study the environmental noise pollution in a city. The observation time and selection of sampling locations are the two most important aspects while taking traffic noise data.

\subsection{Observation Time}

While measuring road traffic noise level, different practices have been adopted, depending upon the need; the observation time may accede a continuous measurement of many years as performed in Valencia and Lanzhou city [11] On the other hand we have the examples of measuring time of 20 and 15 minutes [12]. We have selected our observation time during working hours from 8 a.m. to 8 p.m. and noise level measured for $15 \mathrm{~min}$ at each location point with the interval of 2 hour. To achieve higher accuracy, sampling is done on the random day strategy. So, at each sampling point, the data is collected on more than two randomly selected days in a week.

\subsection{Selection of Sampling Locations}

Different strategies of the selection of sampling locations have been practiced in different parts of the world. Some important of them are summarized here,

a). By using grid over a map

b). Source - oriented sampling

c). Receptor - oriented sampling

d). by using the prior classification of the noise

a). Using grid ( or mesh) over map: In this technique a non-regular grid is used to distribute the measurement points throughout the city. Its main draw backs include:

i. Conclusions strongly depend on gird size

ii. Time and resource consuming

b). Source oriented sampling: In this strategy, the measurement locations are selected randomly mainly on the basis of traffic conditions.

However, the results obtained by this method may not be utilized for any work in future. This is the main disadvantage of this strategy.

c). Receptor - oriented sampling: In this technique, a particular class of receptor for the exposure of noise is investigated.

d). By using the prior classification of noise: This classification may be based on the use of services, the density of residents, or the type of road uses.

The method selected for this work is the regular mach method (Sommerhoff, et al 2004). After the implementation of mash it has been observed that the square of the mash also indicating the area according to the particular economical and commercial activities, so the measurement sites have been divided into four different zones (table 01) according to the particular use of that area as shown in the map (figure: 01 )

Table 1. The Division of Different Urban Zone and their assigned symbols.

\begin{tabular}{lll}
\hline S.No. & Zone & Symbol \\
\hline I. & Residential & 回 \\
II. & Residential and Commercial & $\bullet$ \\
III. & Commercial and service & $\mathbf{0}$ \\
IV. & Cantonment( Residential) & $\bullet$ \\
\hline
\end{tabular}

\subsection{Measurements}

Measurements are taken under suitable climatic conditions i.e. no rain and no wind in the environment, using the digital sound level meter of type II of EXTECH Instruments, Model No.407768 ; with PC interface. The sound level meter is also calibrated before and after each reading using the calibrator of EXTECH Instruments, Model No. 407766 . 


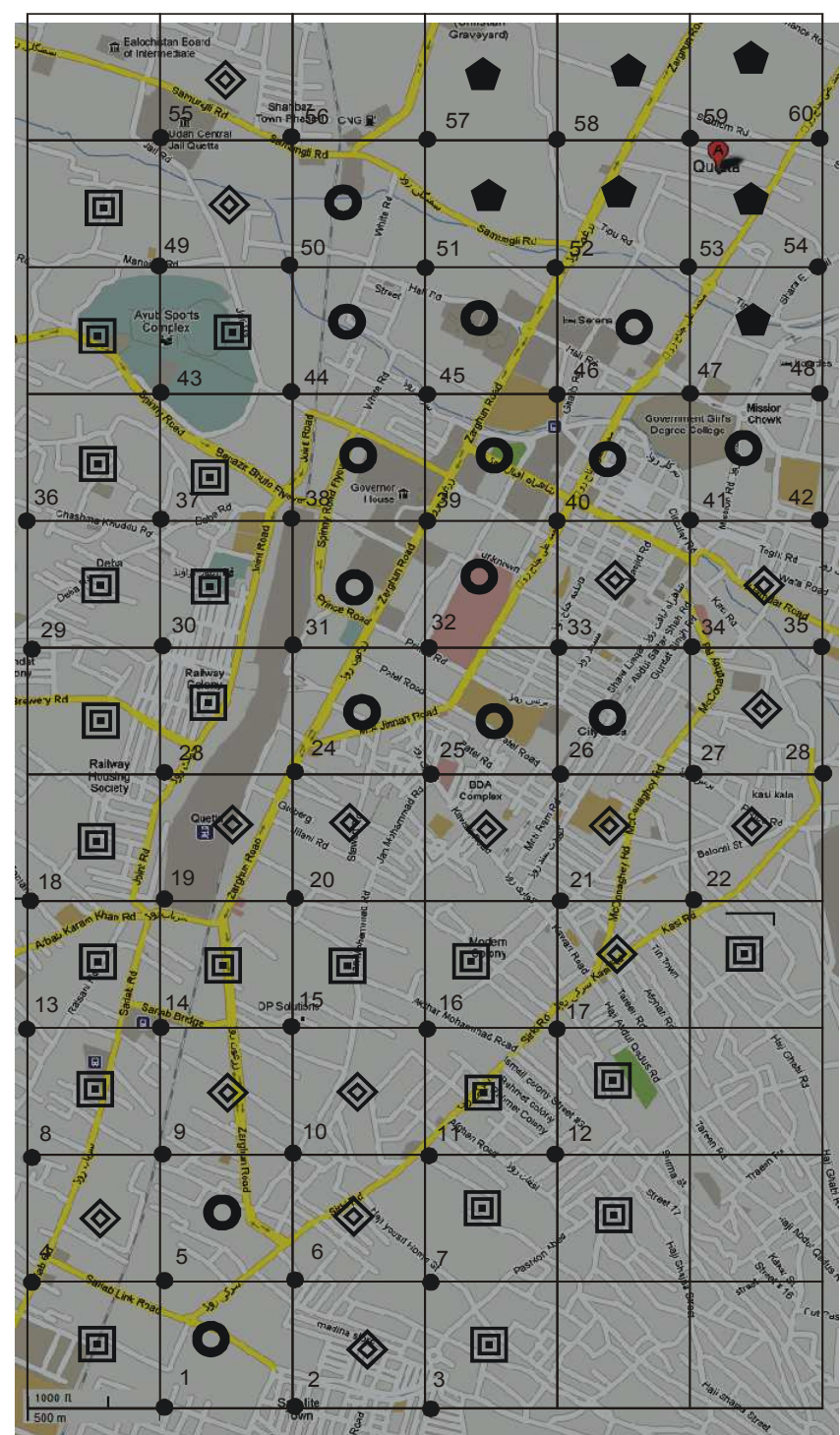

Figure 1. Map of Quetta City (From Google; 05 ${ }^{\text {th }}$ October 2011) with randomly superimposed mesh of $500 \times 500 \mathrm{~m}$ indicating the measurement points.

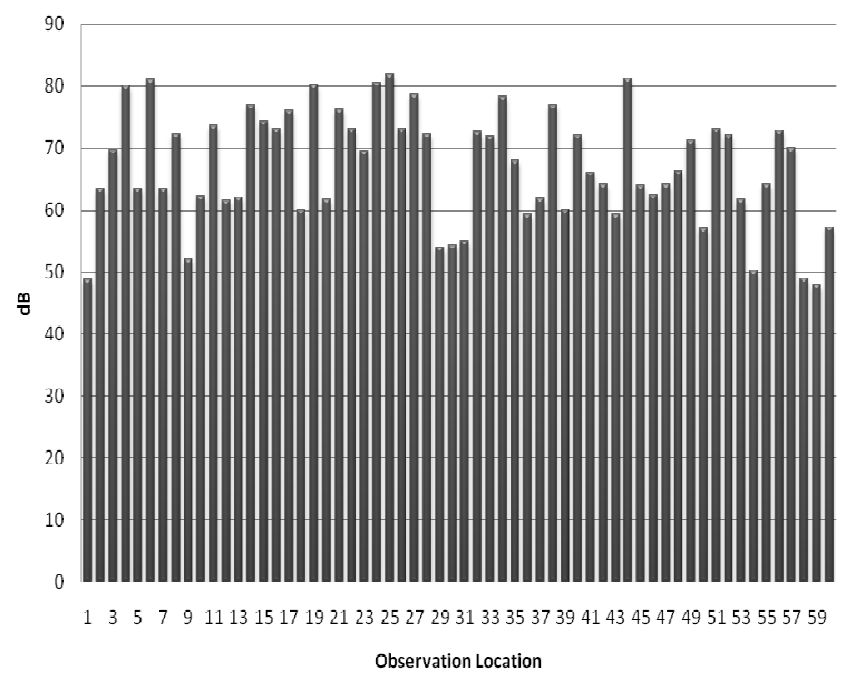

Figure 2. Variation in A-weighted equivalent sound level across the Quetta City.

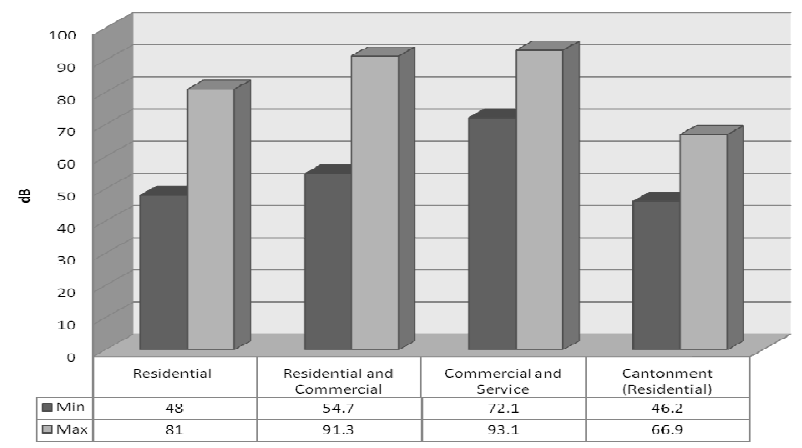

Figure 3. Comparison of Lmax and Lmin, among the different zones of Quetta City.

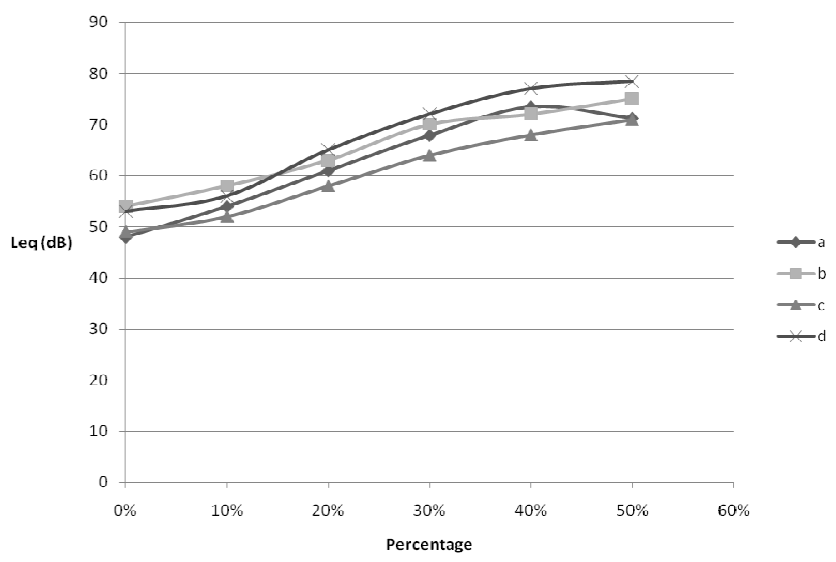

Figure 4. Percentile distribution of Leq measured values on each period, at 60 locations of the city.

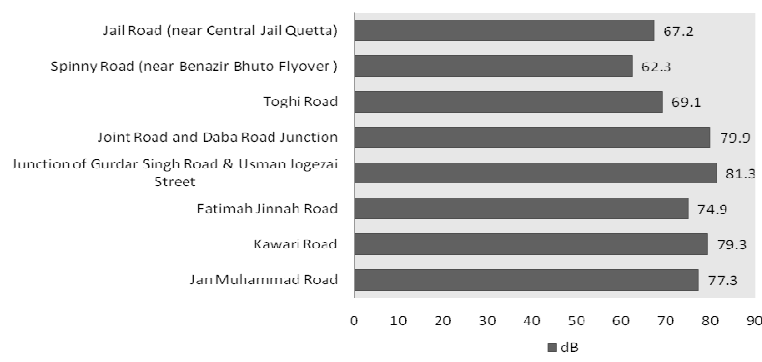

Figure 5. L10 for the eight selected areas in Quetta city.

\section{Results and Discussion}

In this work the noise level is estimated by implementing the regular mash over the city, such that it covers the main area of the city, which includes residential, commercial, mixed (i.e. commercial and residential) and cantonment area. Mash size is selected by keeping in view that it must not be very large so that in that region the sound level $\left(\mathrm{L}_{\text {Aeq }}\right)$ may not vary more then $\pm 5 \mathrm{~dB}$. These mashes contain the different urban zones indicating by the particular symbols as shown in the table. (Table: 1). The area of each mash represents the cover area of $500 \mathrm{~m} \times 500 \mathrm{~m}$, which is implemented on the city map according to the scale (Fig.08). Select the sixty corners of the imposed mash to record the observations, where as the actual readings are made very close to the locations as specified in the table, with its maximum, minimum and average values. (Table:2) 
Table 2. Data of the sixty locations obtained from the randomly superimposed mesh.

\begin{tabular}{|c|c|c|c|c|}
\hline $\begin{array}{l}\text { Location } \\
\text { Number }\end{array}$ & Location Name & $\begin{array}{c}\text { Maximum } \\
\left(L_{\max }\right) d B\end{array}$ & $\begin{array}{l}\text { Minimum } \\
\left(L_{\text {min }}\right) d B\end{array}$ & Average dB \\
\hline 1 & University of Bolochistan Hostel & 62.3 & 47.0 & 48.7 \\
\hline 2 & Satellite Town ( Near Police Station) & 71.2 & 56.9 & 63.4 \\
\hline 3 & Satellite Town ( Jilani Khan Road) & 81.0 & 54.8 & 69.7 \\
\hline 4 & Sariab Road \& Sariab Link Road Junction & 90.0 & 65.3 & 80.0 \\
\hline 5 & Sariab Link Road (Near Sirki Road) & 75.6 & 68.2 & 63.4 \\
\hline 6 & Sirki Road \& Zarghun Road Junction & 87.2 & 64.1 & 81.0 \\
\hline 7 & Haji Yousif Home Street(Near Sirki Road) & 61.9 & 49.6 & 63.5 \\
\hline 8 & Sariab Road & 80.8 & 67.0 & 72.2 \\
\hline 9 & Near Dukani Baba mizar & 60.1 & 52.0 & 52.1 \\
\hline 10 & Jan Muhammad Road & 82.5 & 54.7 & 62.2 \\
\hline 11 & Sirki Road (between HajiYousif St. and Afghan Road) & 85.1 & 62.6 & 73.7 \\
\hline 12 & Afghan Road (Near Sirki Road) & 77.4 & 52.1 & 61.6 \\
\hline 13 & Raisani Road & 72.9 & 53.9 & 62.0 \\
\hline 14 & Sariab Bridge \& Sariab Road Junction & 90.4 & 71.0 & 76.9 \\
\hline 15 & Jan Muhammad Road & 83.7 & 62.8 & 74.3 \\
\hline 16 & Faquire Muhammad Road & 79.2 & 68.5 & 73.1 \\
\hline 17 & Sirki Road (Near Akhtar Muhammad Road ) & 86.4 & 68.9 & 76.1 \\
\hline 18 & Arbab Karam Khan Road & 76.2 & 59.1 & 60.0 \\
\hline 19 & Junction of Arbab Karam Khan, Sariab \& Joint Road & 92.1 & 72.1 & 80.3 \\
\hline 20 & New Al-Gillani Road & 72.1 & 54.0 & 61.8 \\
\hline 21 & Kawari Road(near Gurdat Singh Road) & 81.2 & 59.5 & 76.3 \\
\hline 22 & Kasi Road (Tin Town) & 76.3 & 63.8 & 73.2 \\
\hline 23 & Joint Road(near Railway Housig Society) & 78.4 & 61.3 & 69.5 \\
\hline 24 & Zarghun Road (near M.A. Jinnah Road) & 84.9 & 66.4 & 80.5 \\
\hline 25 & M.A. Jinnah Road (near Kawari Road ) & 93.1 & 64.3 & 82.0 \\
\hline 26 & Junction of Patail \& Shahwak Shah Road & 84.0 & 71.2 & 73.1 \\
\hline 27 & Prince Road (near Maconaghey Road) & 91.3 & 66.9 & 78.6 \\
\hline 28 & Kasi Road (near Kasi Kala ) & 81.0 & 62.1 & 72.3 \\
\hline 29 & Wahadat Colony (inside; near $2^{\text {nd }}$ stop) & 69.2 & 56.0 & 54.0 \\
\hline 30 & Railway Colony (near Railway Ground) & 65.9 & 55.2 & 54.3 \\
\hline 31 & Near Railway Police Station & 64.2 & 56.1 & 55.0 \\
\hline 32 & Prince Road(near civil hospital) & 85.3 & 67.3 & 72.7 \\
\hline 33 & Fatimah Jinnah Road (near $4^{\text {th }}$ street from the Prince Road) & 90.8 & 62.3 & 71.9 \\
\hline 34 & Junction of Gurdar Singh Road \& Usman Jogezai Street & 88.6 & 68.9 & 78.3 \\
\hline 35 & Alamdar Road & 79.5 & 61.4 & 68.0 \\
\hline 36 & Cohashma Khudda Road (Daba) & 72.9 & 56.2 & 59.3 \\
\hline 37 & Daba Road & 79.0 & 58.6 & 61.9 \\
\hline 38 & Joint Road and Daba Road Junction & 80.9 & 57.5 & 76.9 \\
\hline 39 & Zerghun Road( near Governor House) & 69.1 & 53.9 & 60.0 \\
\hline 40 & M.A. Jinnah Road ( near Iqbal Road) & 89.1 & 57.6 & 72.1 \\
\hline 41 & Toghi Road ( near Circular Road) & 90.3 & 60.8 & 66.1 \\
\hline 42 & Dr. Ghalam Nabi Road (near Govt. Muslim Abad High School) & 70.4 & 58.0 & 64.2 \\
\hline 43 & Spinny Road (near Benazir Bhuto Flyover ) & 77.2 & 56.4 & 59.3 \\
\hline 44 & Mir Jafar Khan Jamali Road (near Ayub Sport Complex) & 85.6 & 65.3 & 81.2 \\
\hline 45 & Circular Road (near White Road) & 76.7 & 56.2 & 63.9 \\
\hline 46 & Ghalib Road (near Radio Station) & 79.6 & 58.2 & 62.4 \\
\hline 47 & Share-e-Gulistan Road (near Govt. Girls Degree College) & 86.1 & 66.5 & 64.1 \\
\hline 48 & Near Lourds Hotel & 74.2 & 61.3 & 66.2 \\
\hline 49 & Manu-Jan Road (near Jail Road) & 79.8 & 56.9 & 71.3 \\
\hline 50 & Shahbaiz Town (near White Road) & 68.0 & 54.8 & 57.0 \\
\hline 51 & Hali Road (near Serena Hotel) & 74.9 & 53.2 & 73.1 \\
\hline 52 & Zerghun Road (near Sammungli Road) & 87.1 & 62,7 & 72.1 \\
\hline 53 & Junction of Tipu \& Jinah Road & 72.8 & 52.4 & 61.7 \\
\hline 54 & Shara-e-Tufail (near the street which is jioning the M.A. Jinnah Road) & 68.9 & 51.9 & 50.1 \\
\hline 55 & Jail Road (near Central Jail Quetta) & 90.2 & 53.2 & 64.2 \\
\hline 56 & Sammungli Road (near Shahbaz Town) & 78.4 & 64.8 & 72.8 \\
\hline 57 & Sammungli Road (near White Road) & 80.1 & 62.9 & 70.0 \\
\hline 58 & Tipu Road (between the graveyard and the Zarghun Road) & 66.9 & 46.2 & 48.9 \\
\hline 59 & Stadium Road (near Zarghun Road) & 67.1 & 47.0 & 48.0 \\
\hline 60 & M.A. Jinnah Road (in Cantonment) & 71.8 & 59.2 & 57.2 \\
\hline
\end{tabular}


Due to its appropriate area of $500 \mathrm{mx} 500 \mathrm{~m}$, each mash has become the true representative of the true predominated activities conducted in that region. On the basis of different human activities performed in different regions of Quetta city, we have divided the city into four different zones. We have assigned a particular symbol to each zone depending on the nature of human activities in that zone. Also, we have given a particular symbol to each mash depending on the nature of human activities in that particular region.

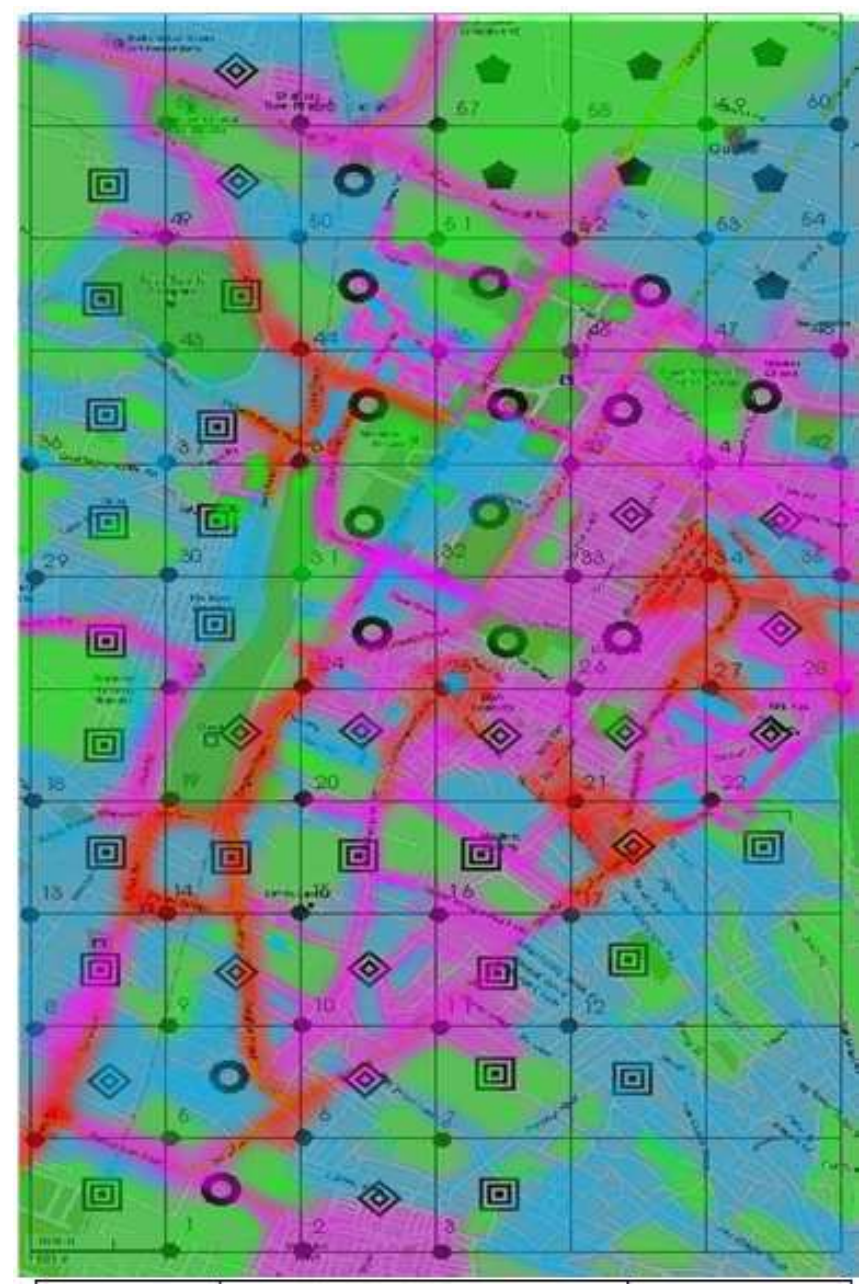

\begin{tabular}{|l|l|l|}
\hline Color & Name of Color & Range \\
\hline & Light Green & $\mathrm{L}_{\mathrm{Aeq}} \leq 49 \mathrm{~dB}$ \\
\hline & Light Blue & $49<\mathrm{L}_{\mathrm{Aeq}} \leq 62 \mathrm{~dB}$ \\
\hline & Magenta & $62<\mathrm{L}_{\mathrm{Aeq}} \leq 76 \mathrm{~dB}$ \\
\hline & Red & $\mathrm{L}_{\mathrm{Aeq}}>76 \mathrm{~dB}$ \\
\hline
\end{tabular}

Figure 6. Noise map of Quetta City

Quetta city can be easily divided into residential area, commercial and service area. However, due to lack of town planning, there are many locations in the city where we cannot properly differentiate between residential and commercial areas. Therefore, we have established a separate zone and named it "Residential and Commercial zone." The commercial and service area is comprised of shops, government and private offices, banks etc. The random super-position of the mash also covers the specific residential area in the cantonment. Hence, the observation locations at the corners of the mash can easily categorized into residential, residential and commercial, commercial and service or cantonment areas. The distribution of the measurement sites is uneven, with the highest percentage for residential areas as illustrated by the zone distribution. (Table: 3 )

Table 3. The distribution of the measurement sites according to the zone.

\begin{tabular}{lcc}
\hline Zone & $\begin{array}{c}\text { Number of Observation } \\
\text { Locations }\end{array}$ & $\begin{array}{c}\text { Percentage(\%) of } \\
\text { the Locations }\end{array}$ \\
\hline Residential & 22 & 36.7 \\
$\begin{array}{l}\text { Residential and } \\
\text { Commercial }\end{array}$ & 18 & 30 \\
$\begin{array}{l}\text { Commercial and } \\
\text { Service }\end{array}$ & 15 & 25 \\
$\begin{array}{l}\text { Cantonment } \\
\text { (Residential) }\end{array}$ & 05 & 8.3 \\
\hline
\end{tabular}

Table 4. Distribution of the measured LAeq values at 60 different sites in Quetta City.

\begin{tabular}{lll}
\hline $\begin{array}{c}\text { A-weighted } \\
\text { equivalent sound } \\
\text { level } \mathrm{L}_{\text {eq }} \mathbf{d B}\end{array}$ & Number of Sites & Percentage ( \% ) \\
\hline $\mathrm{L}_{\text {Aeq }} \leq 50$ & 02 & 3.3 \\
$50<\mathrm{L}_{\text {Aeq }} \leq 55$ & 06 & 10 \\
$55<\mathrm{L}_{\text {Aeq }} \leq 60$ & 06 & 10 \\
$60<\mathrm{L}_{\text {Aeq }} \leq 65$ & 14 & 23.3 \\
$65<\mathrm{L}_{\text {Aeq }} \leq 70$ & 06 & 10 \\
$70<\mathrm{L}_{\text {Aeq }} \leq 75$ & 14 & 23.3 \\
$75<\mathrm{L}_{\text {Aeq }} \leq 80$ & 07 & 11.7 \\
$80<\mathrm{L}_{\text {Aeq }} \leq 85$ & 05 & 8.3 \\
$85<\mathrm{L}_{\text {Aeq }} \leq 90$ & - & - \\
\hline
\end{tabular}

We observed and recorded $\mathrm{L}_{\min }, \mathrm{L}_{\max }$, for all the sixty locations (Table: 4) besides that the noise descriptors $\mathrm{L}_{10}$ and $\mathrm{L}_{\mathrm{eq}}$ were calculated and defined as : [13]

$\mathrm{L}_{10}$ : A specified dBA levels which is exceeded ten percent of the time during the whole period of measurement.

$\mathrm{L}_{\mathrm{eq}}$ : The equivalent continuous $\mathrm{dBA}$ level which has the same energy as the original fluctuating noise for the same given period of time.

The A-weighted equivalent sound pressure level was computed and is defined as follows [14]. (Oyedepo, et al. 2010)

$$
L_{k a q}=10 \log _{10}\left[\frac{1}{N} \sum_{i=1}^{N}\left(\operatorname{anti} \log \frac{L_{t i}}{10}\right) n i\right]
$$

By the analysis of the data it is observed that $77 \%$ of the locations have A-weighted equivalent sound level $\left(\mathrm{L}_{\mathrm{Aeq}}\right)$ more than $60 \mathrm{~dB}$ (Table: 6). Where as $53.3 \%$ of the 
locations have A-weighted equivalent sound level $\left(\mathrm{L}_{\mathrm{Aeq}}\right)$ more than $65 \mathrm{~dB}$.

The Pakistan Environmental Protection Agency which is managed by the Ministry of Environment has set standard of noise in Pakistan. According to these standards the maximum day level noise is $55 \mathrm{~dB}$ for residential area is $65 \mathrm{~dB}$ for commercial areas (Pakistan Environmental Protection Agency). In the study, it is also observed that $77.1 \%$ of the locations in residential areas is higher than the set standards, where as $68 \%$ of the locations in commercial areas is also higher then the set standards.

There are different standards of noise across the world. The US Department of Housing and Urban Development
(HUD) recommends the following standards. ( Zannin, et al. 2002)

$\mathrm{L}_{\text {Aeq }} \leq 49 \mathrm{~dB}-$ Clearly Acceptable

$49<\mathrm{L}_{\text {Aeq }} \leq 62 \mathrm{~dB}-$ Normally Acceptable

$62<\mathrm{L}_{\text {Aeq }} \leq 76 \mathrm{~dB}-$ Normally Unacceptable

$\mathrm{L}_{\text {Aeq }}>76 \mathrm{~dB}$ - Clearly Unacceptable

After the division of HUD standards it is also observed that mixed areas (i.e. residential and commercial) which also includes the residential areas and fall in the category of "Clearly Unacceptable" zone. (Table 5) Theses areas are highly dense for human activities.

Table 5. Classification of different regions of Quetta City on the basis of the US Department of Housing and Urban Development (HUD) standards.

\begin{tabular}{|c|c|c|}
\hline Noise Exposure Class & Locations & Pre-dominated Uses \\
\hline $\begin{array}{l}\text { Clearly Acceptable } \\
{\left[\mathrm{L}_{\mathrm{Aeq}} \leq 49 \mathrm{~dB}\right]}\end{array}$ & University of Bolochistan Hostel, Tipu Road, Stadium Road. & Residential \\
\hline $\begin{array}{l}\text { Normally Acceptable } \\
{\left[49<\mathrm{L}_{\text {Aeq }} \leq 62 \mathrm{~dB}\right]}\end{array}$ & $\begin{array}{l}\text { Near Railway Line, Afghan Road, Raisani Road, Arbab Karam Khan Road, New Al-Gillani } \\
\text { Road, Wahadat Colony, Railway Colony, Near Railway Police Station, Cohashma Khudda } \\
\text { Road (Daba), Daba Road, Zerghun Road( Near Governor House), Spinny Road (near } \\
\text { Benazir Bhuto Flyover ), Shahbaiz Town, Junction of Tipu \& Jinah Road, Shara-e-Tufail, } \\
\text { M.A. Jinnah Road (in Cantonment). }\end{array}$ & $\begin{array}{l}\text { i) Residential } \\
\text { ii)Residential \& } \\
\text { Commercial } \\
\text { iii)Cantonment } \\
\text { (Residential) }\end{array}$ \\
\hline $\begin{array}{l}\text { Normally Unacceptable } \\
{\left[62<\mathrm{L}_{\text {Aeq }} \leq 76 \mathrm{~dB}\right]}\end{array}$ & $\begin{array}{l}\text { Satellite Town ( Near Police Station), Satellite Town ( Jilani Khan Road), Sariab Link } \\
\text { Road, Haji Yousif Home Street, SariabRoad,JanMuhammad Road, Sirki Road, Jan } \\
\text { Muhammad Road, Faquire Muhammad Road, Kasi Road (Tin Town), Joint Road, Junction } \\
\text { of Patail \& Shahwak Shah Road, Kasi Road (near Kasi Kala ), Prince Road, Fatimah } \\
\text { Jinnah Road, Alamdar Road, M.A. Jinnah Road, Toghi Road, Dr. Ghalam Nabi Road (near } \\
\text { Govt. Muslim Abad High School), Circular Road (near White Road), Ghalib Road, Share- } \\
\text { e-Gulistan Road (near Govt. Girls Degree College), Near Lourds, Manu-Jan Road, Hali } \\
\text { Road, Zerghun Road, Jail Road (near Central Jail Quetta), Sammungli Road (near Shahbaz } \\
\text { Town), Sammungli Road (near White Road), }\end{array}$ & $\begin{array}{l}\text { i)Residential } \\
\text { ii)Residential \& } \\
\text { Commercial } \\
\text { iii)Commercial }\end{array}$ \\
\hline $\begin{array}{l}\text { Clearly Unacceptable } \\
{\left[\mathrm{L}_{\text {Aeq }}>76 \mathrm{~dB}\right]}\end{array}$ & $\begin{array}{l}\text { Sariab Road \& Sariab Link Road Junction, Sirki Road \& Zarghun Road Junction, Sariab } \\
\text { Bridge, Sirki Road (Near Akhtar Muhammad, Junction of Arbab Karam Khan, Sariab \& } \\
\text { Joint Road Road ), Kawari Road, Zarghun Road, M.A. Jinnah Road (near Kawari Road ), } \\
\text { Prince Road, Junction of Gurdar Singh Road \& Usman Jogezai Street, Joint Road and Daba } \\
\text { Road Junction, Mir Jafar Khan Jamali Road (near Ayub Sport Complex), }\end{array}$ & $\begin{array}{l}\text { i)Commercial } \\
\text { ii)Residential \& } \\
\text { Commercial }\end{array}$ \\
\hline
\end{tabular}

Table 6. A-weighted Equivalent sound level (LAeq) distribution of the measurements per zone.

\begin{tabular}{|c|c|c|c|c|c|c|c|c|}
\hline \multirow{2}{*}{$\begin{array}{l}\text { A-weighted } \\
\text { equivalent sound } \\
\text { level } L_{\text {Aeq }} d B\end{array}$} & \multicolumn{2}{|c|}{ Residential } & \multicolumn{2}{|c|}{$\begin{array}{l}\text { Residential and } \\
\text { Commercial }\end{array}$} & \multicolumn{2}{|c|}{ Commercial } & \multicolumn{2}{|c|}{ Cantonment (Residential) } \\
\hline & Locations & $\%$ & Locations & $\%$ & Locations & $\%$ & Locations & $\%$ \\
\hline $\mathrm{L}_{\mathrm{Aeq}} \leq 50$ & - & - & - & - & - & - & 02 & 40 \\
\hline $50<\mathrm{L}_{\mathrm{Aeq}} \leq 55$ & 05 & 22.7 & - & & - & - & 01 & 20 \\
\hline $55<\mathrm{L}_{\text {Aeq }} \leq 60$ & 03 & 13.6 & 01 & 5.5 & 01 & 6.7 & 01 & 20 \\
\hline $60<\mathrm{L}_{\text {Aeq }} \leq 65$ & 06 & 27.2 & 02 & 11 & 04 & 27 & 01 & 20 \\
\hline $65<\mathrm{L}_{\mathrm{Aeq}} \leq 70$ & 03 & 13.6 & 03 & 17 & 01 & 6.7 & - & - \\
\hline $70<\mathrm{L}_{\text {Aeq }} \leq 75$ & 05 & 22.7 & 06 & 33 & 04 & 27 & - & - \\
\hline $75<\mathrm{L}_{\text {Aeq }} \leq 80$ & - & - & 04 & 22 & 02 & 13 & - & - \\
\hline $80<\mathrm{L}_{\text {Aeq }} \leq 85$ & - & - & 02 & 11 & 03 & 20 & - & - \\
\hline $85<\mathrm{L}_{\text {Aeq }} \leq 90$ & - & - & - & - & - & - & - & - \\
\hline
\end{tabular}

The distribution analysis per zone illustrate that $11 \%$ of the residential and commercial zones have an environmental noise level greater then $80 \mathrm{~dB}$ and $20 \%$ of the commercial areas also possess the alarming noise level of eighty or more then $80 \mathrm{~dB}$. The pure residential areas at some places also delivered the maximum noise level of 81dB (Figure: 3) due to unchecked silencers and pressure horns of the automobiles.
For the deeper and detail analysis of the noise level, we have divided the day time into the four periods.( Table : 7) It is found that percentile level on noise during the periods "b" and "d" was bit higher as compare to the period "c", due to decrease in the traffic flux, because of less human activities. It is also noted the period " $\mathrm{d}$ " has the highest noise level, which is due to the increased economic activities. 
Table 7. Schedules of the four periods of the observation time.

\begin{tabular}{|c|c|c|}
\hline \multicolumn{2}{|c|}{ Period } & Schedule \\
\hline $\mathrm{a}$ & $1^{\mathrm{st}}$ & $8: 00-10: 00$ \\
\hline $\mathrm{b}$ & $2^{\text {nd }}$ & $10: 00-15: 00$ \\
\hline $\mathrm{c}$ & $3^{\text {rd }}$ & $15: 00-17: 00$ \\
\hline $\mathrm{d}$ & $4^{\text {th }}$ & $17: 00-20: 00$ \\
\hline
\end{tabular}

The equivalent continuous noise level $\mathrm{L}_{\mathrm{eq}}$ is related to the statistical noise level $\mathrm{L}_{10}$ by the following empirical relationship,

$$
\mathrm{L}_{10}=\mathrm{L}_{\mathrm{eq}}+3.0 \mathrm{~dB}(\mathrm{~A})
$$

The 10 percentile noise level is also evaluated and is displayed for the eight selected areas in the mixed zone.

Due to geo-economic and political situation of Quetta city, the economic activities have been dramatically decreased at night. Consequently, the traffic flux practically approaches to few vehicles per hour. Hence, all the zones almost match the standard of the silent zone. That's why our work is confined to day time only.

Noise map is an outstanding tool for controlling noise level in urban areas and thus helps greatly in town planning and is regarded as a useful tool to improve the level of environmental noise pollution. Noise map is considered as a power full tool to get the visual acoustic behavior of any geographical region, hence it is helpful to improve to environmental conditions regarding noise pollution and better town planning. So we made a noise map which is not only based on the data of that sixty location but besides that we have collected the data of thirty other locations.

Noise map is considered as a power tool to comprehend the environmental noise level as noise map can provide the following information:

- Illustrate the exposure of noise and, therefore, may serve as a reference during the process of policy making.

- It provides the path way for implementing the policies that may minimize the noise level.

- It gives the authorities an opportunity to theoretically review and examine their plans for the better environment.

- It helps in enforcing the regional as well as national plans to reduce the new noise resources and it also helps in reducing the noise levels in new areas that are noise sensitive.

- It helps the authorities to monitor the effectiveness of the schemes employed for noise reduction.

- It helps to monitor and study the changing trends in road traffic noise pollution and its impact on the environment.

- It enables the researchers to study the physical and psychology impact of nose on human beings.

\section{Conclusion}

This work has revealed some alarming facts regarding noise pollution in Quetta city. Our analysis shows that maximum sound level in commercial zone is $91.3 \mathrm{~dB}$ and in commercial and service zone is $93.1 \mathrm{~dB}$ which is very high than the limits set by authorities. The residential and commercial zones are at the most high risk because of the intense human activities in these regions; also, noise $\mathrm{L}_{\mathbf{1 0}}$ in most of the area during specific periods of a day was about $81.3 \mathrm{~dB}$.

On the basis of the study it can also be predicted that the noise problem will increase with the passage of time. Therefore, it is essential to address it immediately as later mitigation will become difficult as well as expensive to implant. So the government should establish:

- Educational campaigns to create awareness among the local community

- Regular servicing and tuning of vehicles.

- $\quad$ Fixing of silencers to all automobiles

- Professionals; such as environmental engineers, architects etc. should propose some reasonable solutions to the growing problem of environmental noise pollution while constructing new roads and planning housing schemes.

\section{Acknowledgement}

The corresponding author is very thankful to Dr. Fazli Manan for his valuable discussion and suggestions.

\section{References}

[1] Oyedepo and A. A. Saadu, "Evaluation and analysis of noise levels in Ilorin metropolis Nigeria" Environmental Monitoring and Assessment. 160 (2010) 563-577.

[2] Oyedepo and A. A. Saadu, " A comparative study of noise pollution levels in some selected areas in Ilorin Metropolis Nigeria" Environmental Monitoring and Assessment. 158 (2009) 155-167.

[3] S.P. Parker, Dictionary of Physics, McGraw-Hill. (1997).

[4] R.D. Knight, Physics for Scientists and Engineers: A Strategic Approach, In Traveling Wave, Pearson AddisonWealey, San Francisco. (2008) (pp. 621-622).

[5] H.Y.T Phan, T, Phan. Yano, T. Nishimura, T. Sato and Y.Hashimoto "Community responses to road traffic noise in Hanoi and Ho Chi Minh City” Applied Acoustics. 71 (2010) $107-114$.

[6] S.I. Korfali and M.Massoud "Assessment of community noise problem in greater Beirut area Lebanon" Environmental Monitoring and Assessment. 84(2003) 203218.

[7] Politecnico.C. Mecanica and das Americas.B.J. "Evaluation of noise pollution in urban parks" Environmental Monitoring and Assessment. 118 (2006) 423-433. 
[8] W.Babisch, "Traffic noise and cardiovascular disease" Epidemiological review and synthesis. Noise \& Health., 2(8) (2000) 9-32.

[9] V. Pathak, B.D Tripathi and V.K. Mishra, "Evaluation of traffic noise pollution and attitudes of exposed individuals in working place" Atmospheric Environment. 42 (2008) 3892 3898 .

[10] A.S.M. Barbosa, M.R. Cardoso, "AHearing loss among workers exposed to road traffic noise in the city of Sao Paulo in Brazil” Auris Nasus Larynx. 32 (2005) 17-21.

[11] G.Ma, Y. Tian, T.Ju and Z.Ren "Assessment of traffic noise pollution from 1989 to 2003 in Lanzhou City" Environmental Monitoring and Assessment. 123 (2006) 413-430.
[12] L .Dai, J,Cao, L. Fan and N.Mobed "Traffic noise evaluation and analysis in residential areas of Regina" Journal of Environmental Informatics. 5(1), (2005). 17-25.

[13] A.R. Ismail, M.J.M.Nor, M.R.A. Mansor, M.F.M. Tahir, R.Zulkifli, " Environmental Noise Assessment and Modeling in Malaysia: A Comparative Monitoring Study" European Journal of Scientific Research. 30 (2) (2009) 236-244.

[14] P.H.T Zannin, F.B. Diniz, W.A., Barbosa "Environmental noise pollution in the city of Curitiba, Brazil" Applied Acoustics. 63 (2002) 351-358. 